УДК 376-056.24:159.937

Urszula Klajmon-Lech

ORCID iD 0000 0003-4195-2094

Ph.D., Assistant Professor

Faculty of Ethnology and Education in Cieszyn

University of Silesia in Katowice, Poland

urszula.klajmon-lech@us.edu.pl

\title{
THE IDEA OF SUBJECTIVITY AND DIALOGUE IN THE EDUCATION OF A DISABLED CHILD
}

The subject-oriented perception of a learner is a sine qua non of effective education. The idea of subjectivity in education is related to the idea of dialogicality. Taking into account subjectivity and the need for permanent dialogue is an important task of educating a child with disability. The first range of both ideas is associated with the relations which occur between parents (the first and most important educators and guardians of a child) and specialists (doctors of various specializations, physiotherapists and, first of all, teachers who work with disabled children). The second range concerns the relations between parents and a disabled child. What seems interesting is finding the answer to the question whether the idea of subjectivity and dialogicality is fully implemented in both ranges.

Keywords: dialogue in education; disabled child; education; family; the subjectoriented perception.

(C) Klajmon-Lech Urszula, 2018

«A good educator, who does not smash but liberates, does not drag but lifts, does not mash up but shapes, does not dictate but teaches, does not demand but asks, will experience many soulful moments with children.» Janusz Korczak

\section{Introduction}

\section{The idea of subjectivity and dialogue in education}

As Tadeusz Lewowicki notices, the issue of subjectivity has been present for centuries in the reflection upon human life, its essence, sense and the possibility of human existence in the world, as well as in the questions concerning the aims, contents and 
methods of education (Lewowicki T., 1997, p. 50). What becomes important in the paradigm of subject-oriented education is an individual (Lewowicki T., 1991) - a person taking part in education. Ideologies and social structures step back to the background and have to become subordinated to the individual.

In the pedagogical and psychological approach, subjectivity means that a person is «somebody», has a particular «identity» which distinguishes this individual from others, and that these persons' own activity largely depends on themselves (Tomaszewski T., 1985). As a category which contradicts alienation, it is the activity, creation, initiative, ability and possibility of acting in compliance with the individual system of values (Miluska J., 1990, p. 25). In Paweł Sztompka’s opinion, being a subject means «to want to act and to be able to act» (Miluska J., 1990, p. 25). The term subjectivity is used in contrast to identity as «subjectivity allows for recognizing and considering the ways in which individuals give sense to their own experiences, along with the conscious or unconscious understanding of them, as well as with the available cultural forms through which this understanding is either possible or hindered» (Witkowski L., 1990, p. 58).

Education is the acquisition of subjective identity. It takes place through opening education which cannot block the effort of thinking. Thus, this is the teaching which makes all the knowledge "questionable and not necessary". Teaching and learning is something else than acquiring information for «learning», it is «learning how to listen to such a word which is worth listening - a word which really teaches» (Folkierska A., 1990, pp. 110-111).

The subjective perception of a learner, as most educators claim, is a necessary condition of effective education, which is the opposite of traditional education of clearly directive and intentional nature. The educator should respect learners' personal dignity, value their uniqueness, help them to discover and understand the world and people. Subjectivity in education should take into account: the acceptance of a learner - accepting the learners as they are without prejudice; authenticity - bringing about openness and sincerity in contacts with others; empathic understanding - the ability to feel the mental states of children and youth, especially their way of perceiving the surrounding world (Wagner I., 2000, pp. 367-368). 
Promoting subjectivity in education and viewing it as the only chance for proper education of the society seems insufficient without a critical look at both the chances and threats which it poses. If the learner's subjectivity should be recognized, how can this agree with the subjectivity of teachers? This does not mean the exchange of the existing roles. Can learners' self-fulfilment agree with teachers' self-fulfilment? (Lewowicki T., 1997, pp. 63-64). How to implement the idea of subjectivity in family education? Is it possible to bring together the need of respect for a child with the need of recognizing parental authority? Is the absolutization of the individual not a too extreme way of thinking? Is it not a return to the paedocratic vision? Taking into account children's rights, should the recognized canons enabling communication, choice of the organization of social life, etc., be completely rejected (Lewowicki T., 1997, p. 64)? Does children's subjective participation in education not lead in some cases to dangerous degeneration (some comparison can be made to the situation of school systems in the USA and other Western countries)? What can be confirmed is Ewa Kubiak-Jurecka's statement that it is impossible to introduce subjectivity in education without the earlier or simultaneous democratization of social relations, socialization of education and, first of all, without a change in the awareness of educational subjects - teachers and learners (KubiakJurecka E., p. 41), and without shaping educational competences of parents.

The idea of subjectivity in education is associated with the idea of dialogicality. Dialogue is present in each field of knowledge as an attempt to find answers to the existing problems and difficulties. Joanna Rutkowiak sees the source of the current fascination with dialogue in the crisis which comprises many areas of life. According to her, a turn to dialogue results from the fact that "the empirical and rationalistic ways of explaining the world and the plans to rule the world, which originated from positivism and were a great hope of humanity, have been disappointing in the global dimension - in spite of some particular impressive achievements. However, the significance of these fragmentary successes clashes with the question about what is fundamental" (Rutkowiak J., 1992, pp. 24-25).

Dialogue in the education referring to hermeneutic philosophy is the foundation of communication and, at the same time, of experiencing another person. It is not a method of 
achieving something, for example cognitive effects, nor a game in which people conducting dialogue enter the earlier rehearsed roles. Dialogue is not an act but a process, an on-going conversation which can never be predicted till its end. The truth is known to the people participating in the dialogue, never - outside it. Dialogue does not assume selfconfidence, it allows for treating one's own judgements as uncertain. Its aim is not to negotiate or resign from dissimilarity but to experience the otherness in reality. Dialogue means searching, that is why it is impossible to become «a specialist in dialogue». Scientific knowledge does not constitute its base. A question in dialogue has a «nonpedagogical» nature, which means that it is asked in order to find something out, not to obtain the desired answer. The dialogue understood in this way is not one of educational methods but a lifestyle (Reut M., 1992, pp. 196-198).

Janusz Tarnowski interprets a human being as a dialogical creature who «becomes Me in the contact with You» (Tarnowski J., 2000, pp. 147-148). The sense of education is seen here in leading the learner to apply the attitude of dialogue. Tarnowski distinguishes three types of dialogue - the method, process and attitude. The method of dialogue is the way of communication in which subjects aim at mutual understanding, closeness and collaboration; the process of dialogue occurs when at least one of the elements is embodied; the attitude of dialogue is the readiness for opening to understanding, closeness and collaboration in relation to others (Tarnowski J., 2000, pp. 148-149).

Education is understood by Janusz Twardowski as a meeting which has two dimensions: the vertical - referring to the God, and the horizontal - comprising the contact with humanity (Śliwerski B., 1998, p. 68). This meeting is aimed at raising the child's spirituality through dialogue, which is enhanced by authenticity of the teacher. Father Tarnowski explains the mistakes of modern moral education as resulting from the lack of personal relations: «What is often missing (...) is an important moment: a personal, profound meeting with the Christ, which would cause an inner transformation in the learner. Such a meeting cannot be directed, it is a God's gift. Yet, it can and should be prepared for» (Tarnowski J., 1993, p. 148). The teacher plays an important role here, being able to prepare the learner for the meeting and for the experience of the contact with the God and another human. In the face of the current crisis of modern education and the fall 
of authorities among youth, Janusz Tarnowski encourages to return to the idea of «the master»: «The young are still waiting for the master, someone who can fascinate them. Therefore, the authority of parents as representatives of the God cannot be excluded, but the condition of effective upbringing is not merely the fulfilling of the role of a father and a mother but being them in its complete sense» (Tarnowski J., 1993, p. 66).

Education should be based on the teacher's authority but should not be authoritarian. The educational process must be started by the teacher, who awakens their own inside and constantly goes beyond the self while aiming at perfection (Śliwerski 1998, p. 69). Education as a meeting based on dialogue must be preceded by the attitude of authenticity and engagement, which means «transgressing the own self, breaking the own selfishness, the inner and outer transformation. A human starts to serve regardless the payment and becomes a generous donor» (Tarnowski J., 1993, p. 163).

The attitude of dialogue is strictly associated with recognizing the subjectivity of an individual. Dialogue teaches tolerance, openness, respect for human dignity, which are the constituents of subjectivity. Both subjectivity and dialogicality are considered the leading ideas of education. They are also the highest pedagogical values and goals which should be aimed at by contemporary teachers and learners.

The idea of subjectivity and dialogue gains particular significance in the education of a disabled person. Emphasizing the subjectivity of learners who are often unable to emphasize their opinion and specify their own identity is a challenge for teachers and parents, the task of educating towards dialogue is difficult for them. Quite frequently, they also face the dilemma whether these fundamental educational ideas are adequate in relations with a disabled person. This will be discussed in the further part of the study.

\section{The teacher-parents relations - from the segregated model to the partnership model}

Recognizing subjectivity and the need for permanent dialogue is an important task in the education of a disabled child. The first range of both ideas concerns the relations taking place between parents (the first and most important educators and guardians of a child) and specialists (doctors of various specializations, physiotherapists and, first of all, teachers who work with disabled children). 
These relations undergo transformations associated with the changes in designing the model of collaboration between professionals and parents.

\begin{tabular}{|l|l|l|l|l|}
\hline $\begin{array}{c}\text { TYPE OF } \\
\text { AUTHORITY }\end{array}$ & $\begin{array}{l}\text { PROFESSIONALS - } \\
\text { PARENTS } \\
\text { MODEL OF } \\
\text { COLLABORATION }\end{array}$ & $\begin{array}{c}\text { WAY OF } \\
\text { DECIDING } \\
\text { PARTICIPATION }\end{array}$ & $\begin{array}{c}\text { TYPE OF OF } \\
\text { COMMUNICATION }\end{array}$ \\
\hline $\begin{array}{l}\text { ABSOLUTE } \\
\text { AUTHORITY }\end{array}$ & $\begin{array}{l}\text { Parents trained by } \\
\text { professionals. Parents } \\
\text { involved in the child's } \\
\text { therapy }\end{array}$ & Control over parents & $\begin{array}{l}\text { Professionals with } \\
\text { parents (mostly } \\
\text { mothers) }\end{array}$ & $\begin{array}{l}\text { Dominance of specialist } \\
\text { language, which } \\
\text { perpetuates distance } \\
\text { and authority }\end{array}$ \\
\hline $\begin{array}{l}\text { AUTHORITY } \\
\text { WITH }\end{array}$ & $\begin{array}{l}\text { Family is the centre of } \\
\text { support }\end{array}$ & Collaboration & $\begin{array}{l}\text { Parents (mostly } \\
\text { mothers) and } \\
\text { professionals }\end{array}$ & \begin{tabular}{l} 
Kindness and sincerity \\
\hline AIRECT
\end{tabular} \\
\hline
\end{tabular}

Table 1. Evolution of the parent-professional relationship in the therapeutic process of a disabled child.

Source: Turnbull A. P., Turnbull H. R., 2016.

Many studies confirm the need for active inclusion of parents into therapeutic influence on a disabled child (Cytowska B., 2008, p. 17). These are parents who know their child best and can provide this child with the climate of safety and stability. Even if it is organized frequently and regularly, provisional therapy conducted in early intervention points, rehabilitation and educational centres or in other institutions of this type is not enough in the child's (social, motoric, etc.) rehabilitation. Therefore, what becomes of crucial significance is the earliest and the fullest inclusion of the nearest environment (parents, as well as siblings, grandparents or other relatives if possible) into the therapy of a disabled person.

The perception of the role of parents and the other near family members is changing dynamically, which is illustrated in Table 1. Still recently in Poland, there was the model of «absolute authority» of professionals - doctors, teachers, rehabilitation specialists, which was manifested by the domineering treatment of parents, who were to fulfil specialists' commands with no discussion and no possibility to influence the shape of their child's therapy. Specialists assumed that, as professionally prepared for providing help, 
they could treat parents as if workers. In this way, they created distance between them and the child's surroundings, which was enlarged by specialist vocabulary and burdening parents with numerous duties. This attitude is seen in the opinion of Aga, a member of the internet forum of the association «Razem Możemy Więcej (Together We Can More)»:

«I don't know what to do further. The educator who comes to Szymek every day tells me to do new things for the therapy. Yesterday, I spent the whole evening preparing teaching aids for the classes today. Additionally, she tells me to sit on the lessons and join in, saying: - and now, Szymek, mum will show you how to do it, - etc. I haven't got a free moment. You write, girls, that during your kids' classes you have a cup of coffee or go shopping, I have to engage in my son's therapy as this is the way our teacher sees this». Such type of relations, without dialogicality and the recognition of subjectivity, not only generates parents' distance to professionals, but also makes that parents treat the education of their child as burden and duty, which definitely is not beneficial for this education.

It seems that the most frequent type of the relation in Poland in the «authority with», in which the whole family are the recipients of therapy and family constitutes a support centre. Parents co-decide about the shape of their child's therapy and they take part in it. The characteristic features of the communication between parents and professionals are kindness and sincerity. The ideal model which should be aimed at is the model of «direct authority». Here, the child's therapy and education takes place with the engagement of the whole environment of a disabled person - from specialists and parents, through relatives and neighbours, to the whole local community in which this person lives.

What remains arguable is answering the question how far parents can be engaged in the education of a child with disability and whether they can become main therapist for their child. It seems they should not be burdened with excessive responsibility. They are subjected to a lot of stress and have many duties, which is not experienced by parents of children without disability. Among the factors which make the situation of the family with a disabled child difficult, there are the following:

- feeling of helplessness and lack of knowledge of how to help an ill child; 
- difficulties in establishing emotional and social contact with a disabled child;

- many additional care treatments for a disabled child;

- necessity to resign from professional career and to limit the fulfilment of the social role, the role of a man/woman;

- burdening healthy children with additional duties;

- feeling of guilt and being unfulfilled in the role of a parent;

- feeling of shame and social isolation;

- disbelief in the success of therapeutic activities;

- frequent destruction of the family by parental leaving (most often of the father) (Kwaśniewska G., Wojnarska A., 2004, p. 187).

Parents of disabled children experience the effort and tediousness of teaching their child each activity, each gesture, each word, whereas a healthy child learns as if automatically and unconsciously. The presented burden seems to convince that parents should not take too much responsibility for the therapy of their child - they can be therapists and cotherapists only in a limited scope (Gresnigt H., 1995, pp. 14-19). What is needed to make the education of disabled children effective is the need for mutual complementation of specialists and parents. Still, «the parental interest in professionals' advice and aid is obvious as drawing consequences and shifting them into education in family must remain in their charge. Parents' key position and full responsibility for the child's life cannot be questioned in any case» (Speck O., 2005, p. 472).

\section{Dialogue and the recognition of subjectivity in family}

The basis for the inner family relations is the system of beliefs concerning the child's nature, developmental factors and the main goals of educational activities addressed to this child (Brzezińska A. I., 2009, p. 27). In some parents' opinion, a child is the so called blank slate, where all consecutive experiences are written, and the social surrounding is the fundamental determinant of personal development. Character shaping and teaching are treated as the systems of activities which model the individual according 
to the aim and ideal strictly desired by educators (parents). Thus, the teacher and therapist who the parent becomes takes full responsibility for the shape of the child's therapy, requiring complete subordination in fulfilling the organized tasks and recommendations. In this system, a child is treated as an object of educators' activity, in which there is no place for the attitude of openness and dialogue.

The representatives of the second attitude treat a child as «a creature active from the birth» - a person who tends to contact with other humans from the moment of birth (Brzezińska A. I., p. 27), who is able to start dialogue with them and, owing to this dialogue, wishes to enrich the knowledge and skills necessary for the development. As a person who conducts dialogue, every (also disabled) child is active and capable of expressing their own needs and wishes. Adults (parents) treat this child with respect and recognition of their subjectivity and the right to their own opinion. What has resulted from these two systems of perceiving children and their potentialities is the model of educating a disabled child applied by a family, especially parents. In the 1960s, Władysław Dykcik distinguished three major models of family relations between a disabled child and the parents and other family members (sisters and/or brothers) - the «central», «formal» and the «social circle» model (Dykcik W., 1969, pp. 70-92). Elżbieta Minczakiewicz distinguishes four models (Minczakiewicz E. M., 2005, pp. 72-79):

1. Concentric model

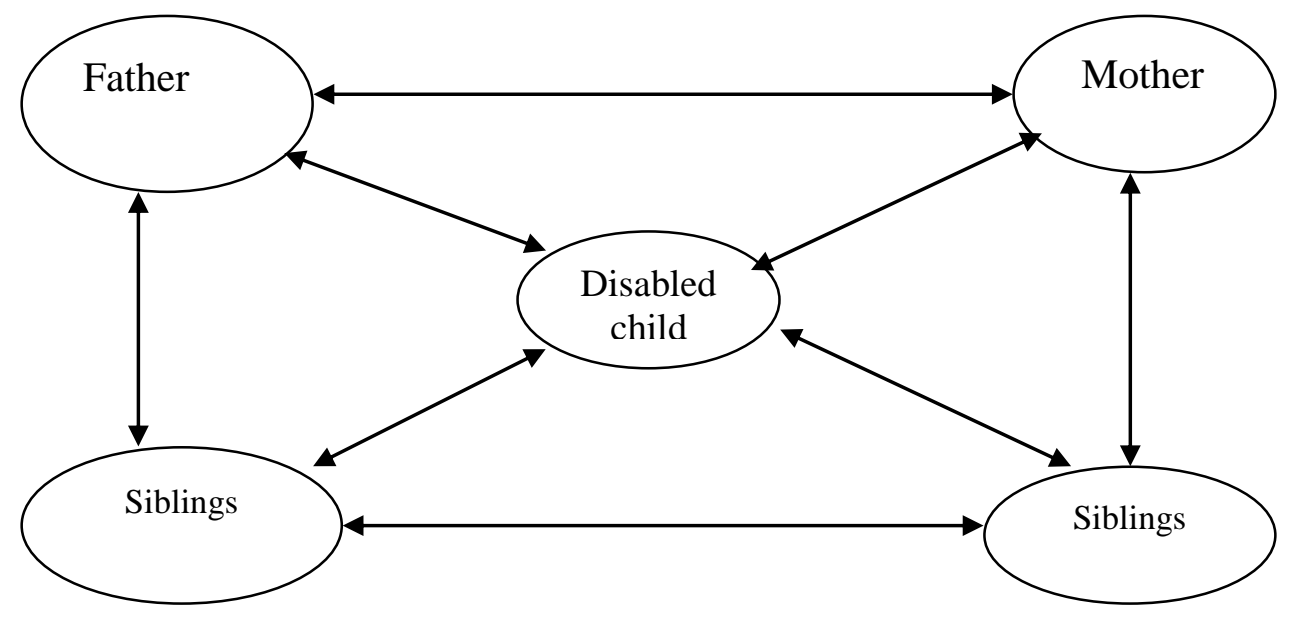

Figure 1. The concentric model of relations in the family with a disabled child. Source: Minczakiewicz E. M., 2005 
In this model, a disabled child is centrally focused on by the family. Parents and other family members concentrate on this child and their needs. The organization of the whole family's life is subordinated to these needs, which often takes place at the cost of the limitation of the needs of brothers and sisters or parents. Parents show overprotectiveness, doing many activities instead of the child, shifting the duties to other children, not teaching the disabled child even the simplest skills. The nearest environment treats this child as a person incapable of independence, someone who relies on others. In the family which applies the concentric model, a child with disability is deprived of subjectivity and often even of human dignity. Such treatment of the child leads to the limitation of their social development, basic skills and interpersonal communication.

2. Formal model

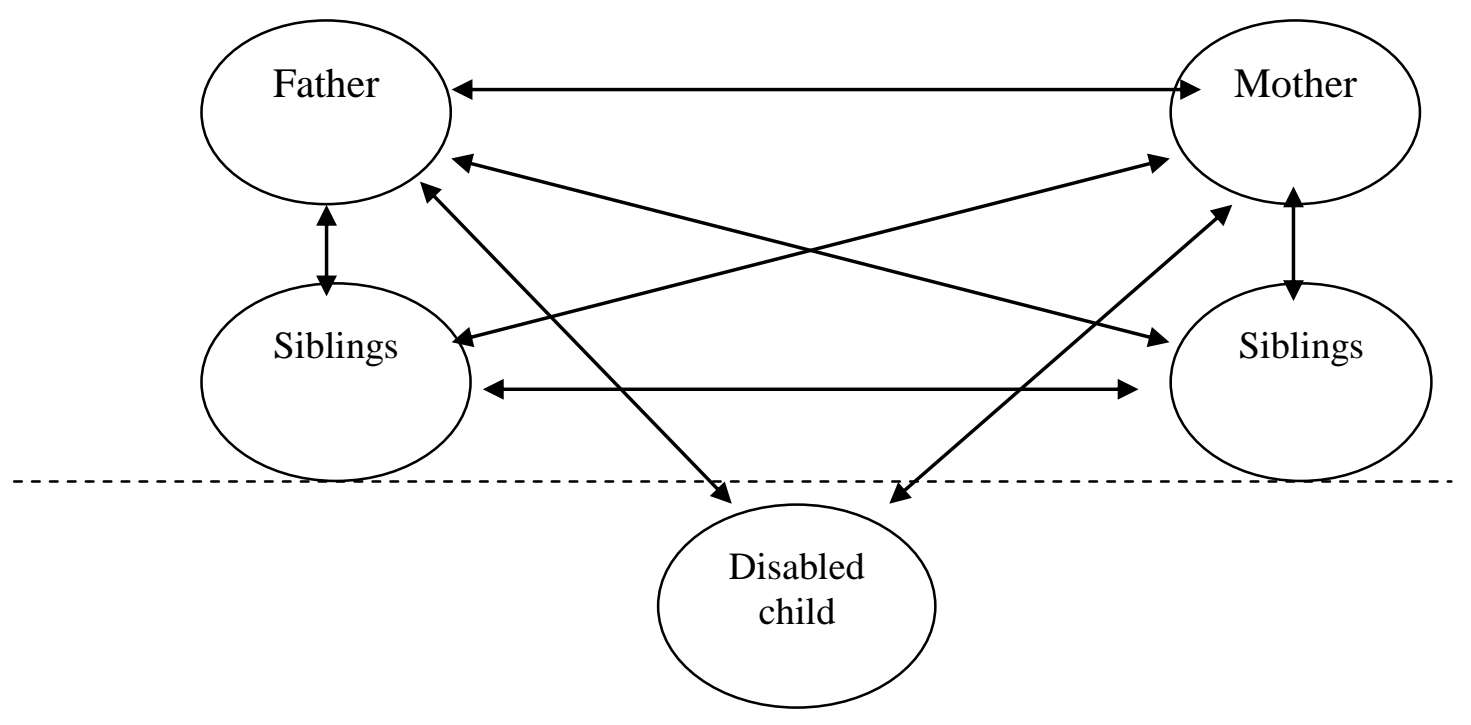

Figure 2. The formal model of relations in the family with a disabled child. Source: Minczakiewicz E. M., 2005

A child in the family which prefers the functional model of relations lives as if on the margin of family life. It is the mother with whom the relations are relatively the closest. Yet, even these relations are limited to fulfilling the child's basic physiological needs, whereas emotional needs, the need for self-fulfilment or safety are not fulfilled or are restricted to the minimum. The deprivation of mental needs and social contacts usually results in the deepening of a disabled child's developmental deficiencies. Children deprived of kindness and attention seek the fulfilment of their feelings in various 
pathological behaviours - they are shy, they often apply an attitude of chronic fear of rejection or low self-esteem. It seems that the functional model is applied by families on the margin of social life. What becomes a duty of social workers and educational institutions is pedagogization of such families and providing multisided support for children raised by them.

3. Model of critical relations

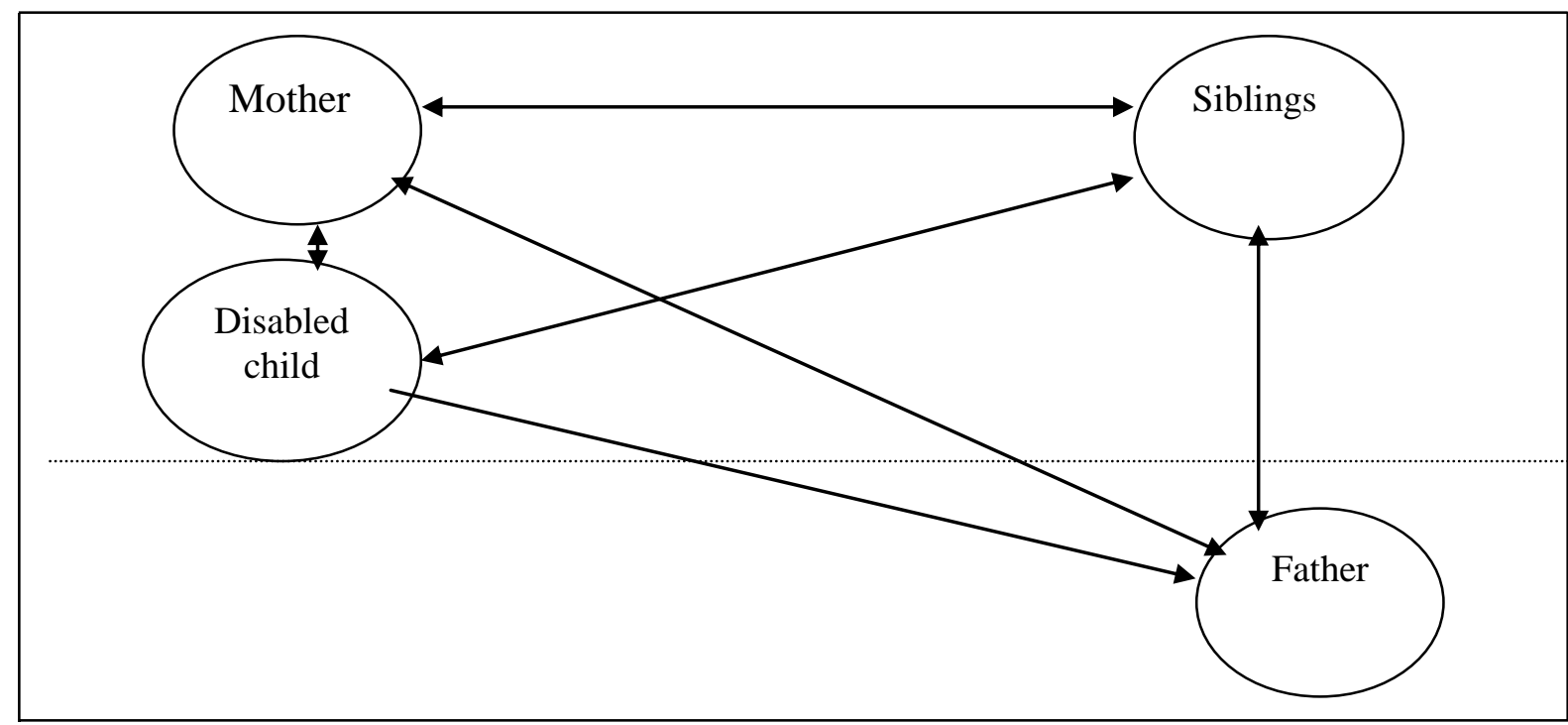

Figure 3. The model of critical relations in the family with a disabled child. Source: Minczakiewicz E. M., 2005

In the discussed model, the figure of a father (less often of a mother) is separated as a result of various causes. In the situation of families with a disabled child, the most frequent reasons of abandoning the family (directly - resulting in family break-up, or mentally - causing the weakening of bonds) by one parent is inability to handle a critical situation, such as experiencing the child's illness, lack of mental resistance and maturity. Children brought up in the family which has applied the model of critical relations are unsure of parental feelings and the feelings of other significant people. They often look for acceptance and authority among other people than parents - the siblings, guardians, teachers. They live in the permanent feeling of anxiety and uncertainty, as well as the fear of rejection. They search for the confirmation of the family feelings towards them and are unable to learn independence. 
4. Model of a social circle

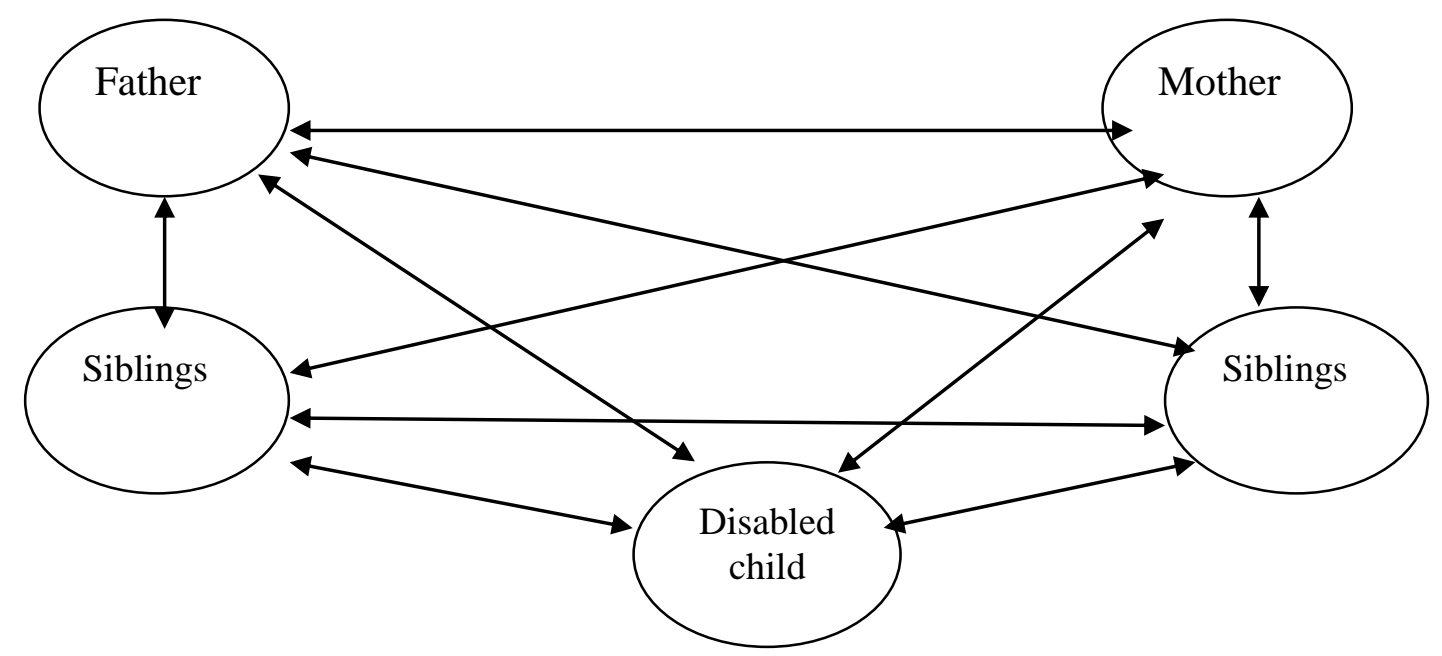

Figure 4. The social circle model of relations in the family with a disabled child. Source: Minczakiewicz E. M., 2005

The optimal model of family relations is the model of a social circle, which assumes equal, truly partnership-based, subjective treatment of all family members. A family which identifies with this model is ruled by natural principles of social coexistence. The relations between parents and children are based on the principle of mutual respect and dialogue. A disabled child growing up in such a family feels loved and accepted, can communicate with the nearests, and is prepared for self-deciding as much as it is possible. Such a model of relations within family is associated with applying the open style of education which assumes that every child (also a disabled one) is active by nature, interested in the world and aiming at learning and understanding it. Children with disability - despite its degree should have the right to free choice of tasks and activities, to free specification of the ways of solving tasks, and to free expression of their own judgement - both concerning themselves (and the effects of their work) and referring to adults (Brzezińska A. I., 2009). With no doubt, granting such freedom and recognizing the child's subjectivity is not easy for parents of a disabled person, especially with deeper disability. Can the intellectually disabled decide about themselves? Can their subjectivity be recognized? Another question has been raised by a philosopher lately: Can a disabled person be recognized as a person? Leaving the philosophical discussion aside, what should be emphasized here with all my 
belief is the need for dialogue with disabled people and allowing them to express their needs and wishes, as well as their need for respecting their subjectivity.

As the recapitulation and confirmation of the theses developed in this study, I would like to quote the guidelines which Elżbieta Minczakiewicz has addressed to parents of disabled children:

1. «Look at the child as at someone climbing hard to a high mountain!

2. Notice their strong points!

3. Learn to listen to your child!

4. Respect the feelings of your child!

5. Every day, try to notice what your child does well. Tell them about this!

6. Share your feelings with your child!

7. Be firm, helping the child in making their small life choices!

8. Make the bonds between home and school tighter! Share with the teacher what you like and admire in your child!

9. Make your child aware that they are someone important, needed, indispensable for you!

10.Create and cherish the appropriate educational climate at home!

11.Have a good time and play with your child because they need you - your presence and acceptance!

12.Give your child the best - love, respect and understanding!

13. React when your child has been harmed by the behaviour of irresponsible people!

14.Talk honestly about all (your own and your child's) expectations!

15.Let your child take part in decisions and choices concerning themselves and your family!

16.Listen to your child's words without judging!

17.Formulate your requirements in a clear way!

18. Make humour a permanent part of your family life because it helps to relieve stress!

19.Never ridicule, embarrass or put shame on your child!

20.Show love to your child without making any conditions!» (Minczakiewicz E. M., 2005, pp. 110-111) 


\section{References}

Brzezińska, A. I. (2009). Drogi dziecka ku samodzielności: między sprawnościq a niepetnosprawnościa. In: A. I. Brzezińska, M. Ohme, A. Resler-Maj, R. (pol)

Kaczan, M. Wiliński: Droga do samodzielności. Jak wspomagać rozwój dzieci i młodzieży z ograniczeniami sprawności. Gdańsk: Gdańskie Wydawnictwo Psychologiczne. (pol)

Cytowska, B. (2004). Sytuacja rodziców i młodzieży z głęboka niepetnosprawnościa intelektualna. In: Z. Janiszewska-Nieścioruk (ed.): Człowiek z niepetnosprawnościa intelektualna. Wybrane problemy osobowości, rodzin $i$ edukacji osób z niepetnosprawnością intelektualną. Vol. 1. Kraków:.Wyd. Impuls. (pol)

Dykcik, W. (1969). Wychowanie i rehabilitacja dzieci głębiej upośledzonych umysłowo w rodzinie oraz placówkach wychowawczo-rehabilitacyjnych. «Materiały Informacyjno-Dydaktyczne ZG TPSD», Komitet Pomocy Dzieciom Specjalnej Troski. Z. 8-9. (pol)

Folkierska, A. (1990). Wychowanie w perspektywie hermeneutycznej. In: Z. Kwieciński, L. Witkowski (eds): Ku pedagogii pogranicza. Torun: Wyd. UMK. (pol)

Gresnigt, H. (1995). Znaczenie wczesnej rewalidacji dla rozwoju matego słabo widzacego dziecka. In: G. Walczak (ed.): Problemy wczesnej rehabilitacji niewidomych $i$ stabo widzacych dzieci. Warszawa: Wyd. WSPS. (pol)

Kubiak - Jurecka, E. (1996). Podmiotowość w wychowaniu a demokratyzacja stosunków edukacyjnych - szanse, ograniczenia, bariery. In: M. Dudzikowa (ed.): Nauczyciel-uczeń, między przemoca a dialogiem : obszary napięć i typy interakcji. Kraków: OW «Impuls». (pol)

Kwaśniewska, G., Wojnarska, A. (2004). Pomoc rodzinie dziecka niepetnosprawnego wybrane kierunki oddziaływań. In: G. Kwaśniewska, I. Wojnarska (eds): Aktualne problemy wsparcia spolecznego osób niepetnosprawnych. Lublin: Wyd. UMCS. (pol)

Kwieciński, Z., Witkowski, L. (1990). (eds): Ku pedagogii pogranicza. Toruń: Wyd. UMK. (pol)

Lewowicki, T.(1997). Przemiany Oświaty. Warszawa: Wyd. Akademickie Żak. (pol) Lewowicki, T.(1991) W strone paradygmatu edukacji podmiotowej. «Edukacja», No.1. (pol)

Minczakiewicz, E. M. (2005). Model wychowania dziecka w rodzinie znaczacym predykatorem jego wychowania. In: E. M. Minczakiewicz, B. Grzyb, Ł. Gajewski: Dziecko ryzyka a wychowanie. Elementarz dla rodziców. Kraków : Wyd. «Impuls». (pol)

Reut, M (1992). Pytanie - nauczanie problemowe - dialog. In: J. Rutkowiak (ed.): Pytanie - dialog - wychowanie. Warszawa: PWN. (pol)

Rutkowiak, J. (1992). O dialogu edukacyjnym. Rusztowanie kategorialne. In: J. Rutkowiak (ed.): Pytanie - dialog - wychowanie. Warszawa: PWN. (pol)

Speck, O. (2005). Niepetnosprawni w społeczeństwie. Podstawy ortopedagogiki. Gdańsk: Gdańskie Wydawnictwo Psychologiczne. (pol) 
Śliwerski, B. (1998). Wspótczesne teorie i nurty wychowania. Kraków: OW «Impuls». (pol)

Tarnowski, J. (1993). Jak wychowywać. Warszawa: Wyd. ATK. (pol)

Tarnowski, J.(2000). Postawa dialogu w pedagogice personalno - egzystencjalnej. In: B. Śliwerski (ed.): Pedagogika alternatywna. Dylematy teorii. Kraków: Wyd. Impuls. (pol)

Tomaszewski, T. (1985). Człowiek jako podmiot i człowiek jako przedmiot. In: J.

Reykowski, O. W. Owczynnikow, K. Obuchowski (eds): Studia z psychologii emocji, motywacji i osobowości. Wrocław : Wyd. Ossolineum. (pol)

Turnbull, A. P., Turbeville, V, Turnbul,1 H. R. (2016). Evolution of Family-Professional Partnerships: Collective Empowerment as the Model for the Early Twenty-First Century.

http://www.beachcenter.org/Research/FullArticles/PDF/P4_Evolution_of_Famil y_Professional8_07.pdf (31.01.2016). (pol)

Wagner, I.(2000). Między akceptacją a manipulacja - refleksje z badań dotyczacych podmiotowości ucznia w szkole (respektowanie praw ucznia). In: J Piekarski, B. Śliwerski (eds): Edukacja alternatywna. Nowe teorie, modele badań i reformy. Kraków: Wyd. Impuls. (pol)

Witkowski, L (1990). Radykalne wizje podmiotu edukacji w dramacie wspótczesności. In: Z. Kwieciński, L. Witkowski (eds): Ku pedagogii pogranicza. Toruń: Wyd. UMK. (pol)

\section{ІДЕЯ СУБ'ЄКТИВНОСТІ І ДІАЛОГУ В ОСВІТІ ДИТИНИ З ІНВАЛІДНІСТЮ}

Клаймон-Лех Уршула, доктор наук, доцент, Факультет етнології і освітніх наук, Сілезький університетв Катовіцах, вул. Бєльська, 62, 43-400 Цешин, Республіка Польща, urszula.klajmon-lech@us.edu.pl

Предметно-орієнтоване сприйняття учня - изе суттєвий крок ефективної освіти. Ідея суб'єктивності в освіті пов'язана з ідеєю діалогічності. Врахування суб'єктивності та необхідності постійного спілкування є важливим завданням виховання дитини з інвалідністю. Перший діапазон обох ідей пов'язаний з відносинами між батьками (першими і найважливішими педагогами та опікунами дитини) та спеціалістами (лікарі різних спеціальностей, фізіотерапевти та, в першу чергу, вчителі, які працюють з дітьми, що мають інвалідність). Другий діапазон стосується відносин між батьками та дитиною з інвалідністю. Становить науковий інтерес відповідь на питання, як ідея суб'єктивності та діалогічності реалізується в обох діапазонах.

Ключові слова: діалог у сфері освіти; дитина з інвалідністю; освіта; предметноорієнтоване сприйняття; сім'я. 


\section{ИДЕЯ СУБЪЕКТИВНОСТИ И ДИАЛОГА В ОБРАЗОВАНИИ РЕБЕНКА С ИНВАЛИДНОСТЬЮ}

Клаймон-Лех Уршула, доктор наук, доцент, Факультет этнологии и образовательных наук, Силезский университетв Катовице, ул. Бельская, 62, 43-400 Цешин, Республика Польша urszula.klajmon-lech@us.edu.pl

Предметно-ориентированное восприятие ученика - это существенный шаг эффективного образования. Идея субъективности в образовании связана с идеей диалогичности. Учет субъективности и необходимости постоянного общения является важной задачей воспитания ребенка с инвалидностью. Первый диапазон обоих идей связан с отнотениями между родителями (первыми и важнейшими педагогами и опекунами ребенка) и специалистами (врачи различных специальностей, физиотерапевты и, в первую очередь, учителя, работающие $c$ детьми которые имеют инвалидность). Второй диапазон касается отномений между родителями и ребенком с инвалидностью. Представляет интерес найти ответ на вопрос, как идея субъективности и диалогичности реализуется в обоих диапазонах.

Ключевые слова: диалог в сфере образования; ребенок с инвалидностью; образование; предметно-ориентированное восприятие; семья. 